\title{
TENSILE STRENGTH OF FIBER FOR SOME TYPE BANANAS (AMBON, KEPOK, SUSU)
}

\author{
G.N Anastasya Sahari ${ }^{1}$, Atus Buku² \\ ${ }^{1}$ Department of Mechanical Engineering, Paulus Christian University of Indonesia, Makassar, Indonesia \\ ${ }^{2}$ Department of Mechanical Engineering, Paulus Christian University of Indonesia, Makassar, Indonesia
}

\begin{abstract}
The purpose of this study was to determine the influence of alcohol soaking treatment on the fiber surface in the physical and mechanical properties of banana fibers and to determine the effect of fiber tensile load when mixed with an epoxy resin with a volume fraction in the form of pull. The results obtained from this study was the influence of alcohol soaking treatment on the surface of banana fiber on the physical properties and mechanical properties of banana fiber are not suitable, because it just makes banana fiber strength becomes strong or fragile. The influence of tensile load of fiber when mixed with an epoxy resin with a volume fraction of 50: 50 in the form of pull sufficient effect on the tensile strength of the composite, as it makes the tensile strength of the composite itself to be increased or stronger.
\end{abstract}

Keywords: Key word1, Key word2, Key word3, and Key word4 etc... $* * *$

\section{INTRODUCTION}

Banana plants / abaca (Musa Textilis Nee) included in bananas (Musacease) are categorized as male bananas, because bananas this, does not produce fruit $[1,2]$. The main production of banana cultivation is in the form of fiber which is well known in international trade as high-quality fiber, because fiber is wrapping Abaca submarine cables or ropes on ships [3,4]. But lately abaca fiber (hereinafter referred to as abaca fibers) is also widely used as raw material for high quality paper pulp such as paper money, checks, filter paper and wrapping paper $[5,6]$.

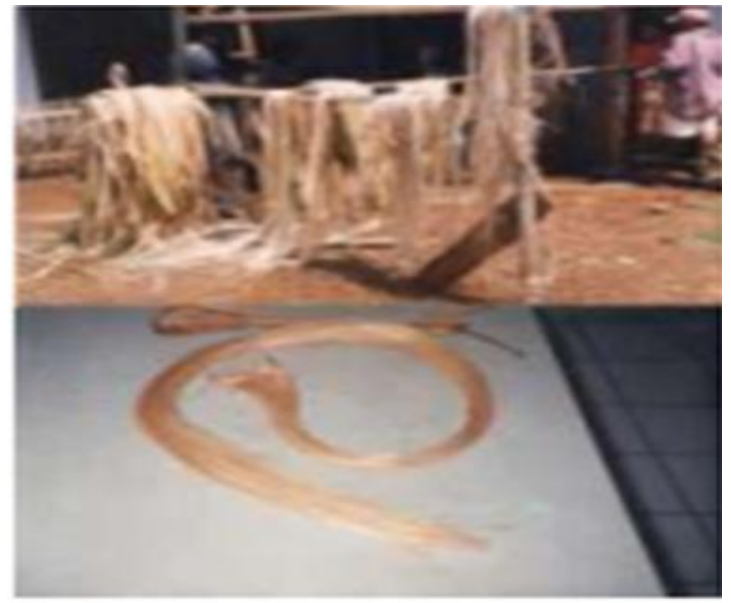

Fig 1. Fiber abaca [7]

But the banana plantation development opportunities in today's increasingly open with more potential international market, mainly to meet the demand of developed countries such as Japan, United States and European countries. The potential of the international market stood at 600,000 tons per year banana fiber $[7,8]$.

\section{MATERIALS AND METHODS}

\section{* Materials}

Fiber banana (Musa Paradisiaca), epoxy resins (as a matrix), catalyst (as a speaker), Alcohol (for treatment).

\section{* Methods}

Raw materials used in the manufacture of the specimens is banana fiber and resin. Intake of fiber will be carried out by immersing the banana skins for 30 days. Making the specimen is done by determining the composition of the resin - fiber. Comparison of the composition of banana fiber and resin with a volume fraction of 50: 50 and the treatment of alcohol content. The next stage of testing will be undertaken is the tensile test.

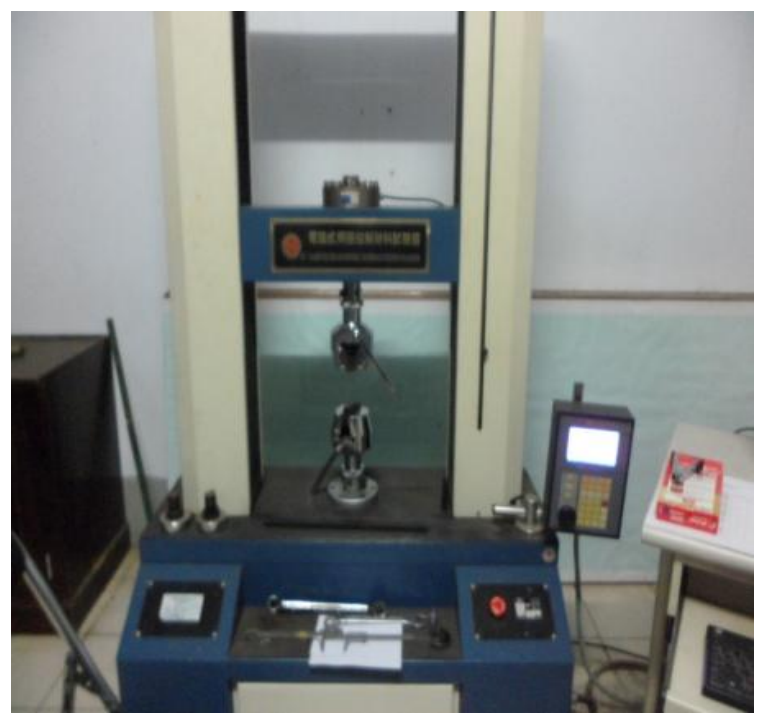

Fig 2 The tensile test equipment 
Table 1 Specifications tools

\begin{tabular}{|c|c|c|}
\hline \multirow{2}{*}{ Capacity } & $\mathrm{Kg}$ & 20000 \\
\hline & $\mathrm{kN}$ & 200 \\
\hline \multirow{2}{*}{ Units } & Load & $\mathrm{N}, \mathrm{kN}, \mathrm{g}, \mathrm{kg}$, ton,ib \\
\hline & Displacement & mm.cm.inch \\
\hline \multicolumn{2}{|c|}{ Load Resolution } & $1 / 20000$ \\
\hline \multicolumn{2}{|c|}{ Load Accuracy } & $\pm 1 \%(0,5 \%$ optional $)$ \\
\hline \multicolumn{2}{|c|}{ Load Amplification } & $\mathrm{x} 1, \mathrm{x} 2, \mathrm{x} 5, \mathrm{x} 10$ Auto range \\
\hline Test width & $(\mathrm{mm})$ & 575 \\
\hline $\begin{array}{l}\text { Crosshead } \\
\text { Travel }\end{array}$ & $(\mathrm{mm})$ & 1440 \\
\hline \multicolumn{2}{|c|}{ Testing stroke } & $\begin{array}{l}\text { Crosshead travel minus } \\
\text { upper/lower grips and } \\
\text { gauge length }\end{array}$ \\
\hline $\begin{array}{l}\text { Range of } \\
\text { test speed }\end{array}$ & $(\mathrm{mm} / \mathrm{min})$ & $0.2-, 200$ \\
\hline $\begin{array}{l}\text { Max, load } \\
\text { at full speed }\end{array}$ & (kgf) & 2000 \\
\hline $\begin{array}{l}\text { Max. speed } \\
\text { at full load }\end{array}$ & $(\mathrm{mm} / \mathrm{min})$ & 50 \\
\hline \multicolumn{2}{|c|}{ Speed Accuracy } & $\pm 0.5 \%$ servo control \\
\hline $\begin{array}{l}\text { Displaceme } \\
\text { nt } \\
\text { Resolution }\end{array}$ & $(\mathrm{mm})$ & 0,001 \\
\hline \multicolumn{2}{|c|}{ Driving Motor } & AC Servo Motor \\
\hline \multicolumn{2}{|l|}{ Power } & $\begin{array}{l}3 \varnothing 22 \mathrm{VAC}, 50 / 60 \mathrm{~Hz} \\
(380 / 415 \mathrm{~V} \text { optional) }\end{array}$ \\
\hline \multicolumn{2}{|c|}{ Dimensions $(\mathrm{cm})$} & $125 \times 90 \times 280$ \\
\hline
\end{tabular}

\section{Standard size and Formulas Used}

Tensile test carried out by using the standard American Society For Testing and Materials (ASTM). Wherein the dimensions of the specimen as shown in the figure below:

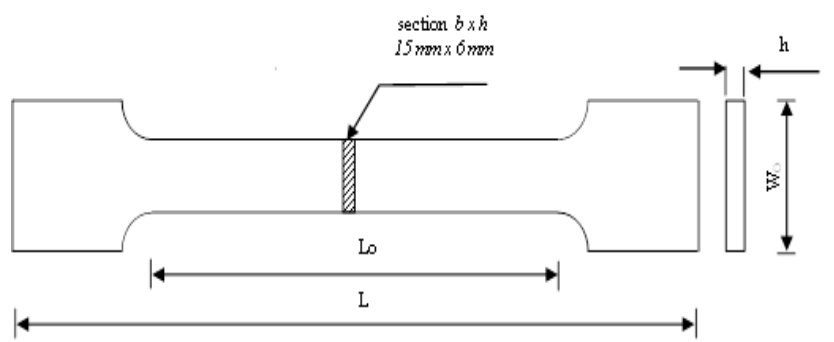

Fig 3. Tensile test specimens

Where:

$\begin{array}{ll}\text { Wo } & =\text { the notch width } 25 \mathrm{~mm} \\ \mathrm{~A} & =\text { sectional area of } 120 \mathrm{~mm} \\ \mathrm{~L} & =\text { long specimen } 150 \mathrm{~mm} \\ \text { Lo } & =\text { long notch } 80 \mathrm{~mm} \\ \mathrm{~h} & \quad=\text { thick specimen } 8 \mathrm{~mm}\end{array}$

To analyze the test data used equation:

The maximum tensile stress $\left(\sigma_{\text {maks }}\right)$

$$
\sigma_{\mathrm{mahs}}=\frac{P_{\mathrm{makg}}}{A}\left(\frac{\mathrm{kgf}^{2}}{\mathrm{~mm}^{2}}\right)
$$

Where:

$\left(\sigma_{\text {maks }}\right) \quad:$ The maximum tensile stress $\left(\left(\mathrm{kgf} / \mathrm{mm}^{2}\right)\right.$

$\mathrm{P} \quad$ : The maximum tensile load (kgf)

A : cross-sectional area $\left(\mathrm{mm}^{2}\right)$

Strain $(\varepsilon)$

$$
\varepsilon=\frac{11}{2} x 100 \%
$$

Where:

$$
\begin{array}{ll}
\varepsilon & : \text { Strain }(\%) \\
\Delta L & : \text { The length due to the pull }(\mathrm{mm})
\end{array}
$$$$
\mathrm{L} \quad \text { : The length at first specimen }(\mathrm{mm})
$$

Material elasticity (E)

$$
E=\frac{\sigma}{g}\left(\frac{\operatorname{lgg} f}{\operatorname{msn}^{2}}\right)
$$

Where:

$\sigma \quad:$ The maximum tensile stress $\left(\mathrm{kgf} / \mathrm{mm}^{2}\right)$

$\varepsilon \quad:$ Strain $(\%)$

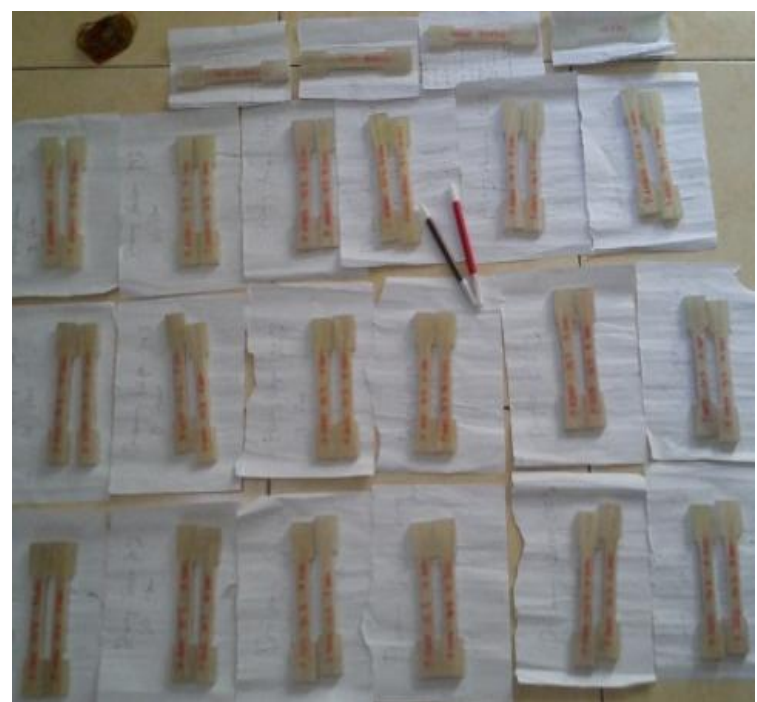

Fig 4 Specimen before being pulled

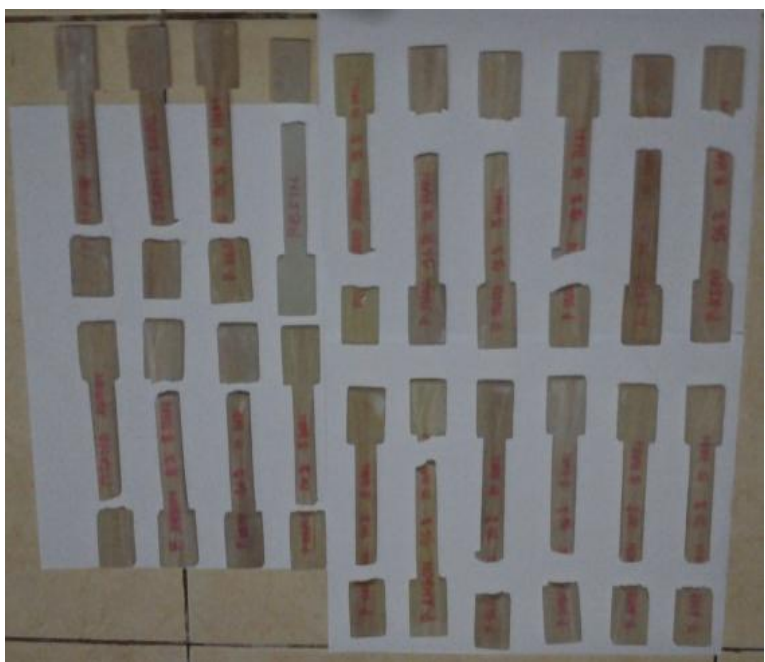

Fig 5 Specimen after being pulled 


\section{RESULT AND DISCUSSION}

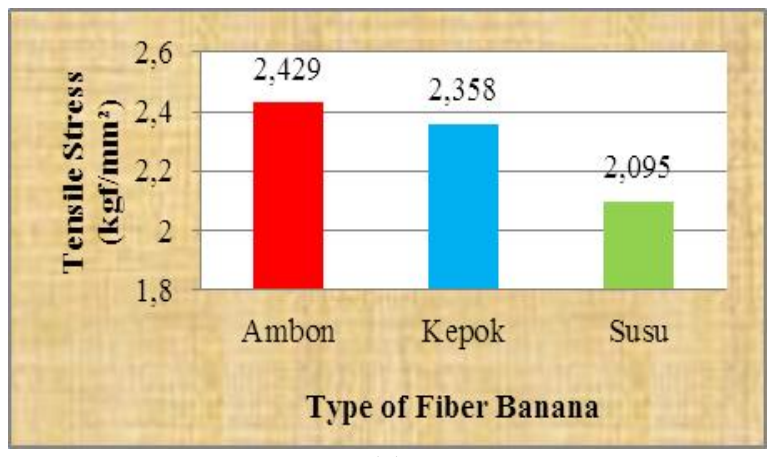

(a)

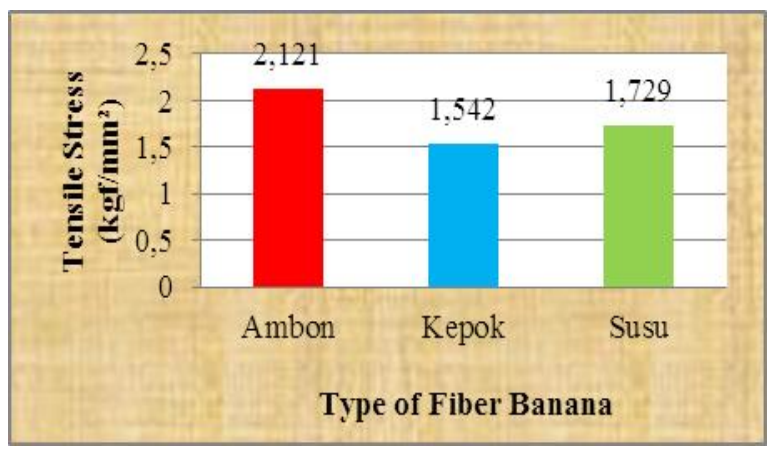

(b)

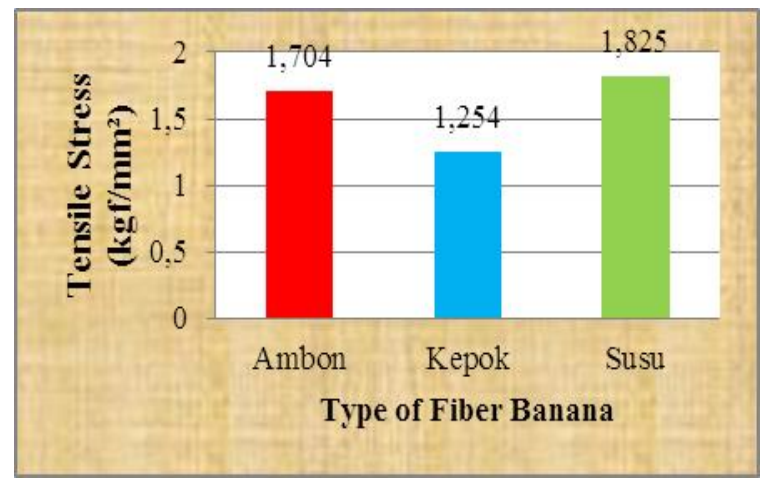

(c)

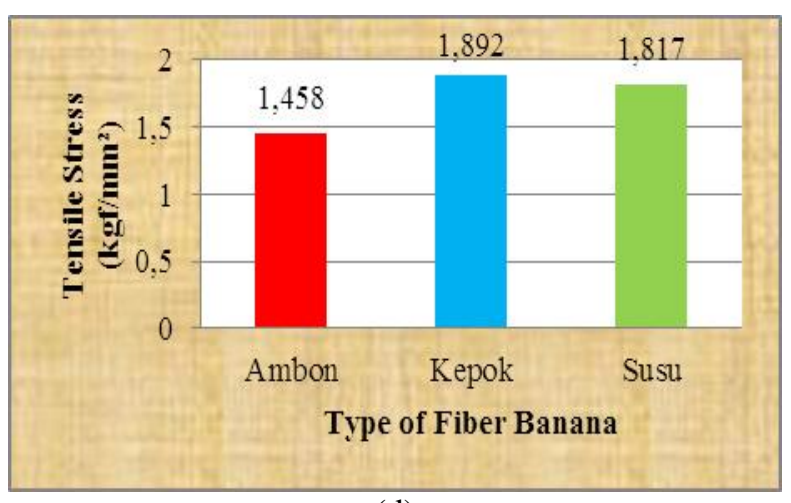

(d)

Fig 6. Relationship between tensile stress and the type of fiber banana on banana fiber composites for 8 days (a) Normal untreated / normal; (b) soaking alcohol 70\%; (c) soaking alcohol $95 \%$; soaking alcohol $96 \%$

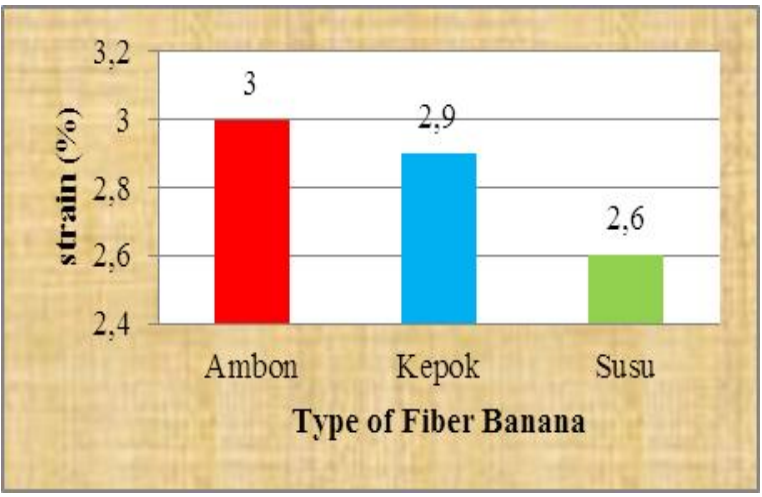

(a)

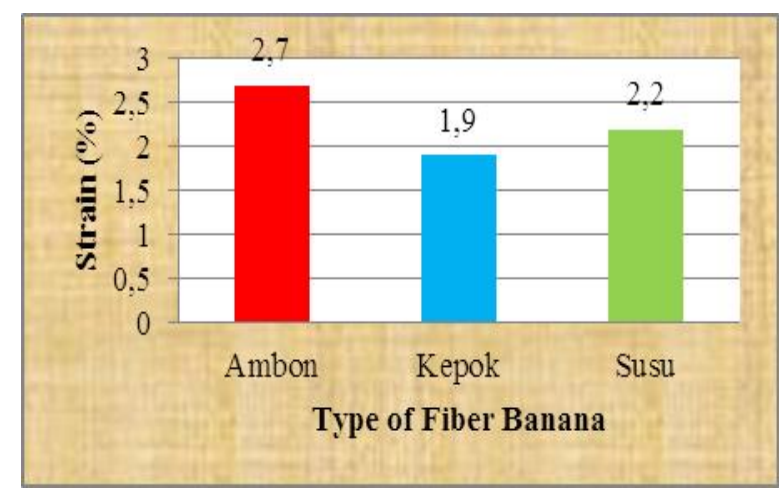

(b)

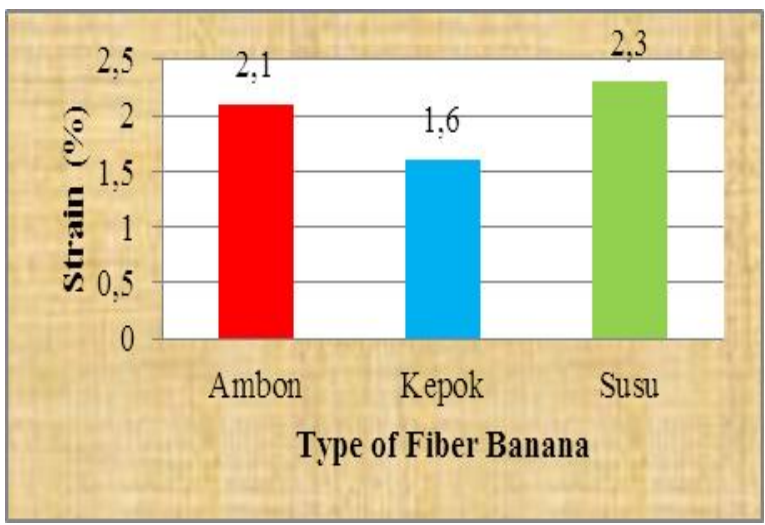

(c)

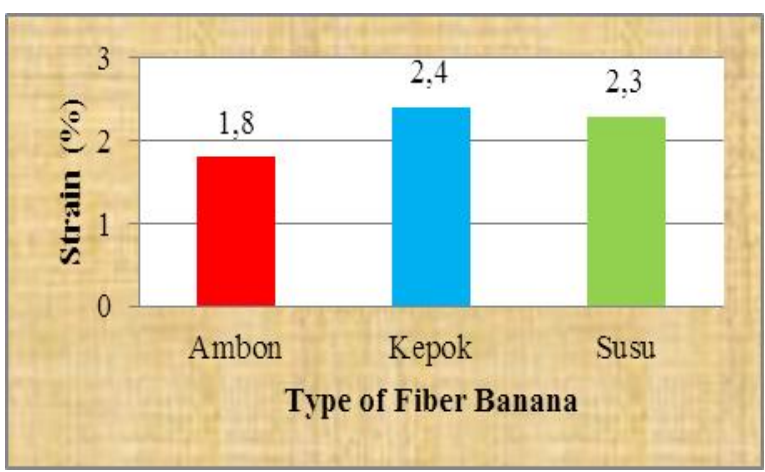

(d)

Fig 7. Relationship between strain and the type of fiber banana on banana fiber composites for 8 days (a) Normal untreated / normal; (b) soaking alcohol 70\%; (c) soaking alcohol $95 \%$; soaking alcohol $96 \%$ 
In the graph of tensile stress with some kind of banana obtained in most large tensile stress occurred in Ambon banana namely $2,429 \mathrm{kgf} / \mathrm{mm}^{2}$ with no through treatment. While the results of the study can also be seen that if the banana fiber is treated makes the fibers become brittle.

Based on the test results obtained by the greatest strain occurred in Ambon banana fiber composite that is $3 \%$. Ambon banana fiber composites are stronger than Kepok banana fiber composites, and Susu. Ambon fiber Banana composites pisan most strongly with normal / without comparison to using the percentage of alcohol content. Treatment using the alcohol content makes the fiber becomes brittle.

\section{CONLUSION}

1. Immersion treatment effect of alcohol on the surface of banana fiber on the physical properties and mechanical properties of banana fiber are not suitable, because it just makes the power of banana fiber itself becomes fragile.

2. The influence of tensile load of fiber when mixed with an epoxy resin with a volume fraction of 50: 50 in the form of pull sufficient effect on the tensile strength of the composite, as it makes the tensile strength of the composite itself to be increased or stronger.

\section{REFERENCES}

[1] Laly A. Pothan, A.L., dan George, N.C., 2009, Dynamic Mechanical and Dielectric Behavior of Banana-Glass Hybrid Fiber Reinforced Polyester Composites, Journal of Reinforced Plastics and Composites.

[2] Laly A. Pothan, A. L., Thomas, S., dan George, J.2010, Tensile and Impact Properties of Banana Fiber/Glass Fiber Hybrid Polyester Composites, Journal of Reinforced Plastics and Composites.

[3] Maleque, A. M., Saiful, A., Sapuan, S.M., 2005, Effect Of Volume Fraction Of Pseudo-Stem Banana Fiber On The Properties Of Epoxy Composite, International Conference on Mechanical Engineering 2005.

[4] Maleque,A. M., Belal, F. Y., 2009, Mechanical Properties Study Of Pseudo-Stem Banana Fiber Reinforced Epoxy Composite, The Arabian Journal for Science and Engineering, Volume 32, Number $2 B$.

[5] Mukhopadhyay,S., Fangueiro, R., Arpaç, Y., Şentürk, Ü.,2008, Banana Fibers- Variability and Fracture Behaviour, Journal of Engineered Fibers and Fabrics, Volume 3, Issue 2-2008.

[6] Radzi , M. H. A., Saleh, M.A.N.,2011, Banana Fiber Reinforced Polymer Composites, Empowering Science, Technology and Innovation Towards a Better Tomorrow.

[7] Singh V. K, , Gope P. C., Sakshi, C., Singh B. D., 2012, Mechanical Behavior of Banana Fiber Based Hybrid Bio Composites J. Mater. Environ. Sci. 3 185-194.

\section{BIOGRAPHIES}

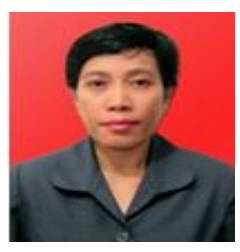

Dr. G. N. Anastasia sahari, Born in Palu, 30 November 1973. Lecturer at the Department of Mechanical Engineering Paulus Christian Indonesia University. Accomplishing doctoral degree at the Indonesia University in the field of composite materials. Some title of the article has generated among: (1) The Production of SiC/Al Ceramic Matrix Composite by Directed Melt Oxidation (Dimox); (2) Effect of wt\% Magnesium on Hardness and wear resistance of Ceramic Matrix Composite $\mathrm{Al}_{2} \mathrm{O}_{3} / \mathrm{Al}$ Product DIMOX

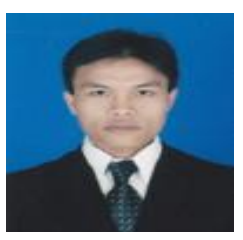

Dr. (candidate) Atus Buku, Born in Huko-Huko, 19 April 1978. Is a lecturer in the Department of Mechanical Engineering Paulus Christian University of Indonesia, Makassar, Indonesia. Currently now taking Doctoral Program at Brawijaya University in Malang, Indonesia. 